\title{
"Golden" Customers and "Bronze" Citizens in CEE Countries
}

\author{
Kristiina Tõnnisson ${ }^{1}$
}

\begin{abstract}
During the Soviet era, the word "citizen" was strongly connected to the existing state-controlled communist party system. "Citizenship" symbolized the ideal Soviet citizen with loyalty, duty and self-sacrifice to the existing order. The new word "customer" appeared together with democratization, freedom and market. Being customer was the realization of both democracy and the capitalist ideology. Customership emerged as a concept distinct from citizenship, and it helped to fill the ideological vacuum in CEE countries. The centrality of consumerism and abandoned citizenship are aspects that might characterize the transformed former Soviet Union and Eastern Europe more than one might expect.
\end{abstract}

\section{Introduction}

Since the major changes in Central and Eastern Europe (CEE) during the last decades of the $20^{\text {th }}$ century (fall of the Berlin Wall, collapse of the Soviet Union, etc), Europe has undergone striking transformations. By now, there are 27 countries whose citizens have also acquired EU citizenship - 12 of them are CEE countries. For many CEE countries, joining the EU was seen as a symbolic return to Europe, based on the concepts of catching up, adaptation and harmonization. The hope and desire to gain EU membership was one of the major incentives to foster transformation processes. Hence, the enlargement of the EU is by no means complete yet. That is why the future of Europe, European citizenship and its meanings are often and heavily discussed both among academics and practitioners.

While developing citizens' sense of belonging to a common Europe and increasing their identity as European citizens, it is important to bring common Eu-

1 Head of the Department of Public Administration, University of Tartu, Tartu, Estonia 
ropean values (freedom, democracy, respect for human rights, cultural diversity, tolerance, solidarity etc) and a shared history to the fore (EU 2005, 8). At the same time, there is a need to acknowledge that CEE countries have experienced a history rather different to that of their Western counterparts during the second part of the $20^{\text {th }}$ century. That is why transformation processes cannot be properly understood as the sum of "positive changes", inspired and evaluated from the West (Lauristin $1997,25)$. On the contrary, in addition to positive changes, they also include the sum of "negative changes".

On the one hand, the breakdowns of multinational states (USSR, Yugoslavia, Czechoslovakia) have laid the ground for the emergence and re-emergence of the new states. The previous political picture of Europe has fallen into separate pieces. On the other hand, a strong movement for a united and common Europe is trying to put these separate pieces into a unified picture again. As the result of this, many CEE countries are simultaneously struggling with both their internal and their external cohesion, with the loyalty of their citizens both towards their own state and towards the united Europe. Even if tensions between state building on the one hand and Europeanization on the other hand exist within every European state, new democracies that have recently undergone considerable transformations of social, political and economic systems are more stressed with building up their own state than old democracies. What makes East and West different in this respect isn't just their resources available and the existing experiences, but also the people's mindset resulting from 50 years of different history. In this framework the concept of citizenship gains a very high importance. It is essential to understand connotations that people in CEE countries (especially in former Soviet republics) might face while discussing it.

\section{The heavy burden of proud Soviet citizens}

During the Soviet era, the word "citizen" was strongly connected to the existing state-controlled communist system. "The doctrine of the 'Soviet people', promoted since the 1960s, was based on political and ideological ... sentiments" (Piattoeva 2009,728 ). Soviet citizenship was supposed to represent Soviet unity, power of the working class people and honor of the USSR. "Friendship of peoples" (druzhba narodov) promoted by the regime was expected to reflect the harmony all Soviet people were experiencing in the USSR. It was assumed that citizenship represents all "positive" features of the Soviet system expressed in one's worldview, moral ideals and norms of behavior. The dissemination of this concept was perceived as an important means of consolidating society and ensuring the integrity of the existing system. Even bringing up children and young people was based on this concept. It was commonly stated that Soviet citizenship offered the highest possible privileges.

Citizenship and loyalty to the communist party lay at the center of the publicly embraced value system. Hence, they constituted one single system. Propaganda and 
public information echoed these objectives. Soviet citizenship was assumed to replace all possible identities. All people were highly encouraged to belong to the communist party. Metaphorically speaking, citizenship symbolized the ideal Soviet citizen with loyalty, duty and self-sacrifice to the existing order. The discourse of Soviet citizenship with its "happiness to all" was justifying drawbacks in society. Public information in society was aimed to pursuade the public of the undoubted superiority of the existing social system. Counterarguments or suspicions were almost never publicly addressed or discussed.

Thus, nowadays in CEE countries, "citizenship" might for many people still be connected to the feelings and value systems reinforced together with this word during the Soviet era. For them, it often meant expressing one's fake loyalty to the political system and the regime. As a citizen, one was supposed to take part in fake elections knowing that the decisions had been made long before by the only existing communist party. As a citizen, one was supposed to be a proud Soviet citizen carrying real human values and fighting against "Western rotten capitalism" and life style. At the same time people could not act on the free market, because there was none. They could not travel free. People could not think, talk and behave freely, because they were citizens of the Eastern block. Even if universal citizenship and lesser differentiations of wealth allowed people a relative freedom to move, or not to move, within the USSR (Sahadeo 2007, 573), people's lives were heavily controlled and standardized. "Many people discovered that they had been oppressing and betraying their real 'self' because of fear and conformity ... The disclosure of 'hidden selves' is an important individual aspect of transition, full of personal drama and trauma." (Lauristin 1997, 38). One common denominator behind all this pain, sorrow and guilt was Soviet citizenship. People paid a very high mental and psychological price for this citizenship.

Based on the above, it is easy to understand why everything associated with citizenship and the state had a bad reputation during the Soviet era. The words "Soviet state" and "Soviet citizen" were often mentioned in the processes of harassing people, of deporting them to Siberia, of pushing them to live double lives as strangers in their own countries. Suspicion and sometimes even hate towards the state was one of the characteristics that many people carried over to the new economic, political and social context. Even after 20 years of democracy, one can still witness similar mindsets among the public in CEE countries. This attitude might become more dangerous in a developmental process than one might assume at first glance. It might create serious problems for establishing a new concept of citizenship and building up both the EU in general and the states within it. E.g. in the case of Estonia, it is argued that "Estonia's most serious problem is probably that there is no prevailing state identification on the part of her citizens. There is no étatisme at all, not even a concept of state. While this might actually sound attractive to the opponents of 'state', it leads to serious problems that Estonia cannot afford. These include the lack of automatic citizens' loyalty, co-operation within the government, 
or true respect for legal or administrative decisions." (Drechsler 1995, 112). Even while referring to a particular ex-Soviet country, this could be applied to a certain degree to all CEE countries. The desire to abandon the Soviet past and to move on to a free democratic world pushed people to abandon the concept of citizenship together with its Soviet connotation.

\section{Customer orientation as the expected "white ship" from the West}

In order to dissociate from the Soviet system after the changes, people were encouraged to get new identities. Promoted by the most visible ship flag of the changes - the commercial sector -, it was pleasant and easy to adapt to the concept of customer. "Throughout postsocialist Europe, the realm of the commercial has been transformed from a sphere dominated by state production interests to one that carefully appeals to consumers' needs and desires" (Patico and Caldwell 2002, 285). The neglect of the concept of citizenship was thus, on the one hand, a manifestation of the finally arrived and long expected changes and, on the other hand, a way to break apart from the past aiming to abolish the previously existing system. "Being a proud citizen" was replaced with "being a proud customer". The Soviet everyday formula among the people - "Soviet in form, not so Soviet in content" - was replaced in many CEE countries by the formula "democratic in form, capitalist in content". Verdery $(2000,176)$ argues that the radical change of the property regime that followed the collapse of socialism "alters the very foundations of what 'persons' are and how they are made". The gradual reformulation of what it meant to be an individual, a citizen and a consumer in the new situation and how the boundaries between these roles were shifting was a question faced by most of the people.

No doubt, one of the biggest trajectories of the transformations was the economic change. Suddenly the real market appeared. Soviet people were happy to leave behind their "hats" of being Soviet citizens and to put on the new, desirable and more Western-looking "hats" of being customers. Cherishing the concept of customer has its roots in the desire to catch up with the Western world, its life style and standards. Being a customer was perceived as the means of connecting the existing situation to modern, Western development. It constituted a bridge connecting the good old things with new good things. While citizenship was and continued to be there, customer orientation meant everything new that people were aiming for freedom of choice, economic development, etc. It is easy to understand why people abandoned their identity of being "citizens" and wanted to become "customers". It meant a change of their entire world and mindset. The mentioned desire matured up to the point of believing that being customer contains everything needed in life.

Thus, the word "customer" appeared together with freedom, market and Western goods. Being a customer was the realization of both democracy and the capitalist ideology. Both democratization and marketization were mutually inter- 
related changes in post-communist countries (Lauristin 1997, 26). They were often conceived as intertwining concepts allowing people to feel free and to make their own choices. Being a customer and customer orientation were often perceived as a certain aspect of the democratization process. The concept of citizenship had to make space for the concept of the customer. This change was quick and efficient. Customer orientation together with customer rights replaced without delay the "failing concept of citizenship". Customership emerged as a concept distinct from citizenship. It easily filled the ideological vacuum in CEE countries.

\section{Conclusions}

Since gaining or regaining their independence, most CEE countries have tried to pursue reform strategies for establishing functioning democratic states. It meant building up new structures and systems both for the state and the market. In many countries, reforms have had a rather strong focus on the market. These reforms have been guided by the values of efficiency and productivity rather than substantive democracy (Bouckaert et al. 2008). Hence, CEE countries are somehow haunted by their Soviet legacy and the discrepancy between the concepts of citizenship and customer orientation. In many cases, customer orientation as an expression of changed circumstances and obtained freedom occupied a superior position in comparison to the citizenship. Scarcity and relative homogeneity were the norms of Soviet citizenship before the changes. After the changes, shopping centers started to display the postmodern dreams of these people. In addition, since the concept of citizenship contains some degree of loyalty to one's country and some degree of a determination to serve its interests, while the concept of customer orientation is concentrated on one's personal needs, it is easy to understand why in blurred political and ideological circumstances such a conceptual change could happen rather smoothly.

Even when most CEE countries have greeted joining the EU with high expectations and great joy, one might discover at a closer look that an opportunity to be a "European customer" might be appreciated much higher than an opportunity to be a "European citizen". Consumerism has long occupied a key role in postsocialist citizens' relations to each other, the state and the world (Patico and Caldwell 2002, 287). Both "golden customers" and "bronze citizens" have their legacy and roots. Then again, such anti-state attitudes might start to contribute to the further alienation of the citizens from the state and public affairs. The centrality of consumerism and abandoned citizenship are aspects that might characterize the transformed former Soviet Union and Eastern Europe more than one might expect. 


\section{Acknowledgements}

The author would like to thank the Regional Center of Public Administration Reform implemented by UNDP BRC, who offered financial support for participating at Trans-European Dialogue in Helsinki, 6-7 July 2009.

\section{References}

Bouckaert, G., J. Nemec, V. Nakrošis, G. Hajnal and Tõnnisson, K. (eds). 2008. Public Management Reforms in Central and Eastern Europe. Bratislava: NISPAcee Press.

Drechsler, W. 2005. “The Re-Emergence of 'Weberian' Public Administration after the Fall of New Public Management: The Central and Eastern European Perspective." Halduskultuur 6, 94-108.

European Union (EU). 2005. Europe for Citizens Programme, 2007-2013. Available online at: http://ec.europa.eu/citizenship/how-to-participate/doc92_en.htm, version valid as of 1 January 2009, accessed 28 October 2009.

Lauristin, M. 1997. “Context of Transition.” In M. Lauristin and P. Vihalemm (eds). Return to the Western World. Tartu: Tartu University Press, 25-40.

Patico, J. and M.L. Caldwell. 2002. "Consumers Exiting Socialism: Ethnographic Perspective on Daily Life in Post-Communist Europe." Ethnos 67 (3), 285294.

Piattoeva, N. 2009. "Citizenship and Nationality in Changing Europe: A Comparative Study of the Aims of Citizenship Education in Russian and Finnish National Education Policy Texts." Journal of Curriculum Studies 41 (6), 723-744.

Sahadeo, J. 2007. "Druzhba Narodov or Second-Class Citizenship? Soviet Asian Migrants in a Post-Colonial World." Central Asian Survey 26 (4), 559-579.

Verdery, K. 2000. "Privatization as Transforming Persons." In S. Antohi and V. Tismaneanu (eds). Between Past and Future: The Revolutions of 1989 and Their Aftermath. Budapest: Central European University Press, 175-197. 